\title{
Metastatic Childhood Soft Tissue Sarcoma
}

National Cancer Institute

\section{Source}

National Cancer Institute. Metastatic Childhood Soft Tissue Sarcoma. NCI Thesaurus.

Code C8066.

A sarcoma that arises from the soft tissues during childhood and has spread from the original site of growth to another anatomic site. 